А. М. Зельницький, кандидат педагогічних наук, професор,

Національний університет оборони України імені Івана Черняховського

\title{
ЯКІСТЬ ВИЩОЇ ВІЙСЬКОВОЇ ОСВІТИ ЯК РЕЗУЛЬТАТ ФУНКЦІОНУВАННЯ ПЕДАГОГІЧНОЇ СИСТЕМИ ВВНЗ
}

У статті окреслено проблеми якості підготовки здобувачів вищої військової освіти на засадах компетентнісного підходу. Схарактеризовано педагогічну систему ВВНЗ як структуровану иілісну сукупність взаємопов'язаних складників освітньої діяльності вищих військових навчальних закладів. Розглянуто особливості впровадження в освітній процес інноваційних педагогічних технологій, щуо мають максимально сприяти досягненню здобувачами вищої військової освіти визначеного рівня якості освіти. Наголочено на дочільності впровадження в теорію та практику вищої військової школи концепиії гарантування якості підготовки військових фахівиів, де гарантом має виступати вищий військовий навчальний заклад.

Ключові слова: якість; якість вищої військової освіти; компетентність; педагогічна система; педагогічна технологія.

Постановка проблеми. Серед пріоритетних напрямів досліджень у системі вищої військової освіти проблема якості підготовки офіцерських кадрів постала як найбільш актуальна, особливо - упродовж останніх кількох років. Ії загострення зумовлене низкою чинників, у тому числі - недостатнім рівнем професійної підготовленості офіцерів до успішного ведення бойових дій в зоні антитерористичної операції (далі - ATO) на сході країни. Це проявилося більшою мірою на початковому етапі АТО, в якому віддзеркалилися певні прорахунки щодо розвитку оборонної сфери держави, Збройних Сил України, системи військової освіти тощо. На теперішній час ситуація змінилася на краще. Разом $з$ тим, залишаються невирішеними чимало проблемних питань. Щодо системи військової освіти, то надзвичайно важливою $є$ проблема гарантування якості підготовки військових фахівців - проблема, що залишається й досі малодослідженою у педагогічній теорії та практиці. Їі розв'язання несе в собі виразну цілеспрямованість на досягнення необхідного кінцевого результату у підготовці високопрофесійних офіцерських кадрів, здатних ефективно виконувати службово-бойові функції в умовах мирного i воєнного часу. Власне професія офіцера, як така, зобов'язує на запровадження подібних підходів. Гарантування якості освіти $є$ результатом застосування в освітньому процесі відповідних педагогічних технологій як головного процесуального компоненту створеної педагогічної системи (ПС) у ВВНЗ. Створення оптимальної ПС та ефективне іiі функціонування має максимально сприяти якості підготовки здобувачів вищої військової освіти.

Аналіз останніх досліджень і публікацій. Якість освіти, як одна 3 найважливіших педагогічних проблем, є ще недостатньо дослідженою на теперішній час і потребує окремого спеціального аналізу. Про це свідчать результати опрацювання автором низки науково-педагогічних, методичних та інших інформаційних джерел, в яких представлено чимало підходів, починаючи із визначення категорії “якість", i, завершуючи питаннями оцінювання якості освіти та управління нею. Загальнотеоретичні підходи 
щодо якості освіти та управлінські аспекти висвітлено у працях таких вчених: С. Ніколаєнка, А. Субетто, С. Гончаренка, В. Кременя; щодо якості освіти як ступеня відповідності освітнім стандартам та очікуванням тих, хто навчається - у працях Г. Ковальової, С. Шишова, В. Кальней; щодо технологічних та моніторингових аспектів забезпечення якості освіти - у працях В. Беспалька, О. Локшиної, Н. Кузьміної, А. Майорова, С. Хрикова.

У зарубіжній педагогічній теорії та практиці проблема якості освіти доволі часто розглядається спільно $з$ проблемою застосування інноваційних педагогічних технологій, про що свідчать дослідження таких вчених як М. Кларк, Ф. Персиваль, Г. Веллінгтон, П. Мітчел, М. Вульман, С. Сполдінг, С. Ведемейер, Р. Томаста, Маассен та ін. 31996 року в Англії один раз у два роки проходять конференції, за матеріалами яких випускаються книги "Aspects of Educational Technology".

Чільне місце у дослідженні даної проблеми посідають й праці військових вчених-педагогів i психологів. Серед них М. Корольчук, Є. Мануйлов, М. Нещадим, В. Осьодло, В. Ягупов. За останні роки Національним університетом оборони України імені Івана Черняховського виконано науково-дослідні роботи, що безпосередньо стосуються якості вищої військової освіти. Серед них: “Інновція-2008”, “Якість-2011”, “Зміст освіти", “Перспективи розвитку військової освіти”, “Моніторинг у системі вищої військової освіти”.

Разом 3 приділенням такої пильної уваги загальним питанням щодо якості вищої та вищої військової освіти, проведений нами аналіз наукових досліджень у цій сфері дозволяє зробити певний висновок. Феномен якості підготовки майбутніх офіцерів у ВВНЗ, визначення рівня сформованості та об'єктивного оцінювання їхньої компетентності на сьогодні є недостатньо вивченим, що доводить актуальність даного дослідження.

Мета статті полягає у дослідженні феномену якості вищої військової освіти як похідної від функціонування педагогічної системи ВВНЗ та застосування інноваційних педагогічних технологій при формуванні у здобувачів вищої військової освіти визначених професійно важливих якостей та компетентностей.

Виклад основного матеріалу. Реалізація мети даного дослідження передбачає послідовне проходження певних етапів. Перший з них пов'язаний 3 дефінітивним аналізом та уточненням відповідних категорій та понять, а саме: "якість"; “компетентність"; "забезпечення якості вищої освіти"; “гарантування якості вищої освіти”; “педагогічна система ”.

У міжнародному стандарті якості ISO:9000 (International Organization for Standardization - Міжнародна Організація зі Стандартизації) поняття “якість” представлене на певному рівні узагальнення як ступінь відповідності сукупності притаманних характеристик об'єкта визначеним вимогам [1].

У Законі України “Про вищу освіту” якість вищої освіти визначається як “...сукупність якостей особи з вищою освітою, що відображає іiі професійну компетентність, ціннісну орієнтацію, соціальну спрямованість і обумовлює здатність задовольняти як особисті духовні i матеріальні потреби, так i потреби суспільства" [2]. 
Гегель, досліджуючи категорію “якість", акцентував увагу на іiі властивостях, що $є$ суттю прояву якості в конкретній системі взаємодій чи відносин. На думку видатного філософа - “...будучи внутрішньо обумовленими якістю, властивості відкривають можливості їі пізнання і "кордони” як феномена диференційованості якості від інших якостей” [3, с. 312].

Спільними в розумінні категорії “якість” у наведених підходах щодо іiі тлумачення $€$ сукупність характеристик суб'єкта та ступінь їх відповідності визначеним вимогам. Такими суб'єктами в системі військової освіти виступають курсанти (слухачі), їх характеристиками - професійно важливі якості та компетентності, а вимогами - визначений відповідно до освітніх стандартів рівень сформованості цих компетентностей.

Компетентність [лат. competens (competentis) - належний, відповідний], компетентний - той, що знає, володіє необхідною інформацією, авторитетний у чомусь [4, с. 369]. Поняття “компетентність" у Законі України "Про вищу освіту" представлене як динамічна комбінація знань, вмінь і практичних навичок, способів мислення, професійних, світоглядних і громадянських якостей, морально-етичних цінностей, яка визначає здатність особи успішно здійснювати професійну та подальшу навчальну діяльність і $\epsilon$ результатом навчання на певному рівні вищої освіти [2]. Відповідно до міжнародного стандарту ISO:9000 поняття “компетентність" (від англ. competence - здатність) представлено як доведену здатність застосовувати знання і навички задля досягнення визначених результатів [1]. Інтерпретацію наведених понять, з урахуванням особливостей військової служби офіцера, можна представити так. Компетентність офіцера - це доведена ним здатність до постійного самовдосконалення, до успішного застосування набутих знань, умінь, навичок, інших особистісних якостей при виконанні службовобойових функцій у змінних умовах професійної діяльності в мирний $\mathrm{i}$ воєнний час. Аналіз наведених понять "якість" i "компетентність" $€$ підгрунтям щодо наповнення змістом ключової для даного дослідження категорії - “якість освіти” та її похідних.

Однією з таких похідних є забезпечення якості освітньої діяльності та якості вищої освіти. У Законі України "Про вищу освіту" представлено структуру та зміст складників цього поняття, у тому числі - систему внутрішнього забезпечення якості, що стосується безпосередньо ВВНЗ [2].

Система внутрішнього забезпечення якості включає:

визначення принципів та процедур забезпечення якості вищої освіти;

здійснення моніторингу та періодичного перегляду освітніх програм;

щорічне оцінювання здобувачів вищої освіти, науково-педагогічних i педагогічних працівників вищого навчального закладу та регулярне оприлюднення результатів таких оцінювань;

забезпечення підвищення кваліфікації педагогічних, наукових і науковопедагогічних працівників;

забезпечення наявності необхідних ресурсів для організації освітнього процесу, у тому числі самостійної роботи тих, хто навчається, за кожною освітньою програмою; 
забезпечення наявності інформаційних систем для ефективного управління освітнім процесом;

забезпечення публічності інформації про освітні програми, ступені вищої освіти та кваліфікації тощо.

Представлена система забезпечення вищими навчальними закладами якості освітньої діяльності та якості вищої освіти $\epsilon$ необхідною, але недостатньою умовою підготовки висококваліфікованих фахівців, особливо, що стосується професійної підготовки офіцерських кадрів для Збройних Сил України. Професія офіцера, по відношенню до багатьох інших цивільних професій, має значні особливості. Вони пов'язані, перш за все, з покладенням на Збройні Сили України функцій оборони України, захисту іiі суверенітету, територіальної цілісності і недоторканності. Відтак, офіцер, як представник Збройних Сил України, несе високу особисту відповідальність: за бойову готовність підрозділу; за успішне виконання особовим складом бойових завдань у постійно змінюваних, екстремальних умовах впливу стресогенних факторів середовища і діяльності; за ефективне використання сучасних систем озброєння і військової техніки; за бойову підготовку, виховання, військову дисципліну, морально-психологічний стан особового складу, за його здоров'я i життя; за своєчасне та якісне виконання наказів та розпоряджень командирів і начальників. Тому до якості підготовки офіцерів висуваються підвищені вимоги, які повинні реалізовуватися у спосіб, що має гарантувати визначений рівень сформованості необхідних компетентностей та професійно важливих якостей.

У словосполученні гарантування якості вищої військової освіти ключовим словом є гарантія [франц. garantie < garant - поручитель], де: гарант - державний орган (установа, підприємство чи особа), що бере на себе відповідальність у виконанні певних зобов'язань, дає гарантію щодо чогонебудь; гарантія - забезпечення, запорука в чому-небудь [4, с. 152]. Гарантування якості освіти визначено пріоритетною проблемою Болонського процесу. Ї̈ї розв'язання $є$ основою створення європейського освітнього простору. На сьогоднішній день в Свропі функціонує мережа 3 гарантування якості у вищій освіті - ENQA, де розробляються єдині стандарти, методики та рекомендації.

Проблему гарантування якості вищої військової освіти поки що не розроблено концептуально. Певні кроки щодо ії розв'язання в теоретичному плані і впровадження у педагогічну практику вищої військової школи вже зроблено. Це знайшло своє віддзеркалення в окремих публікаціях у фахових збірниках та матеріалах наукових і науково-практичних конференцій. В окремих 3 них визначено найбільш глобальне поняття - "політика гарантування якості військової освіти" [5;6]. Сутність цього поняття стосується розробленості концептуальних засад щодо створення і регуляції необхідних умов для виконання ВВНЗ державного замовлення на підготовку військових фахівців з визначеним рівнем сформованості в них необхідних компетентностей. Щодо власне поняття "гарантування якості вищої військової освіти”, то, на нашу думку, його можна розуміти як поруку ВВНЗ (BВНЗ є гарантом якості освіти) з виконання державного замовлення на 
підготовку військових фахівців 3 рівнем сформованості визначених компетентностей у кожного 3 них не нижче встановленого [5]. Так, наприклад, мінімальний рівень сформованості інтегральної компетентності здобувача вищої військової освіти може складати 65\%. Це становить 0,65 від еталонного показника - 1,0, що відповідає оцінці “5” у п'ятибальній оцінній шкалі. При цьому, мінімальний рівень сформованості кожної з окремих компетентностей, які входять до складу інтегральної, не повинен бути нижчим за 60\%, що згідно із рекомендаціями СКТС (європейська кредитнотрансферна накопичувальна система) відповідає рівню “задовільно”.

Зрозуміло, що прояв компетентностей має бути об'єктивно оціненим і визначеним щодо ступеню їх сформованості не тільки кількісно (відсотками, балами), але й якісно (розробленістю системи критеріїв, за якими здійснюватиметься кількісне оцінювання). Подібний підхід щодо оцінювання якості освіти може бути успішно реалізованим із застосуванням методів кваліметрії. Кваліметрія (від лат. квалі -якість та древньогрецького метріо вимірювати) - галузь науки, яка вивчає і реалізує методи кількісної оцінки якості $[4$, с. 346]. У даному контексті йдеться про кількісну оцінку ступеня досягнення цілей освіти, а відтак - і ступеня відповідності якості освіти вимогам освітніх стандартів. Гарантування якості освіти є похідною від ефективного функціонування педагогічної системи ВВНЗ та іiі основних складників: якості кадрового ресурсу; якості умов, у яких відбувається освітня діяльність; якості процесу формування професіоналізму.

Поняття "педагогічна система" (ПС).у навчальній та монографічній педагогічній літературі остаточно не сформоване, хоча деякими авторами здійснено спробу це зробити. Аналітичному огляду розробленості даної проблеми присвячено один 3 розділів монографії М.I. Нещадима [7, с. 451], де досліджено i проаналізовано погляди на сутність, структуру i функціонування ПС відомих учених-педагогів і психологів. Серед них: С.І.Архангельський, Ю.К. Бабанський, А.В. Барабанщиков, В.П. Беспалько, Дж. Брунер, С.У. Гончаренко, Т.А. Ільїна, Н.В. Кузьміна, А.О. Лігоцький, А.С. Макаренко, Н.Г. Ничкало, П.І. Підкасистий, І.П. Підласий, В.А. Сластьонін, В.О. Сухомлинський, І.Ф. Харламов, В.В. Ягупов.

Більшість із зазначених учених-педагогів розглядає ПС як цілісне утворення, де системотворчим елементом є мета, а результатом - ступінь їі досягнення. Між цими двома елементами й низка інших, які пов'язані між собою таким чином, що вся система налаштована на підготовку випускника ВВНЗ із заданими якостями.

Розглядаючи структуру ПС ВВНЗ, ми спиралися на iï визначення. “Це відкрита соціальна система, що існує у змінному освітньому середовищі $\mathrm{i}$ являє собою структуровану сукупність взаємопов'язаних складових освітньої діяльності, що в процесі взаємодії функціонують як єдине ціле 3 метою забезпечення якості підготовки військових фахівців відповідно до стандартів вищої освіти " [8, с. 41]. У представленій структурі (Рис. 1) виокремлено основні іiі складові - від соціально-державного замовлення на підготовку військових фахівців, відбору кандидатів на навчання - до здобуття ними статусу офіцера-випускника, призначення на первинну посаду у війська та отримання даних зворотних зв’язків. 


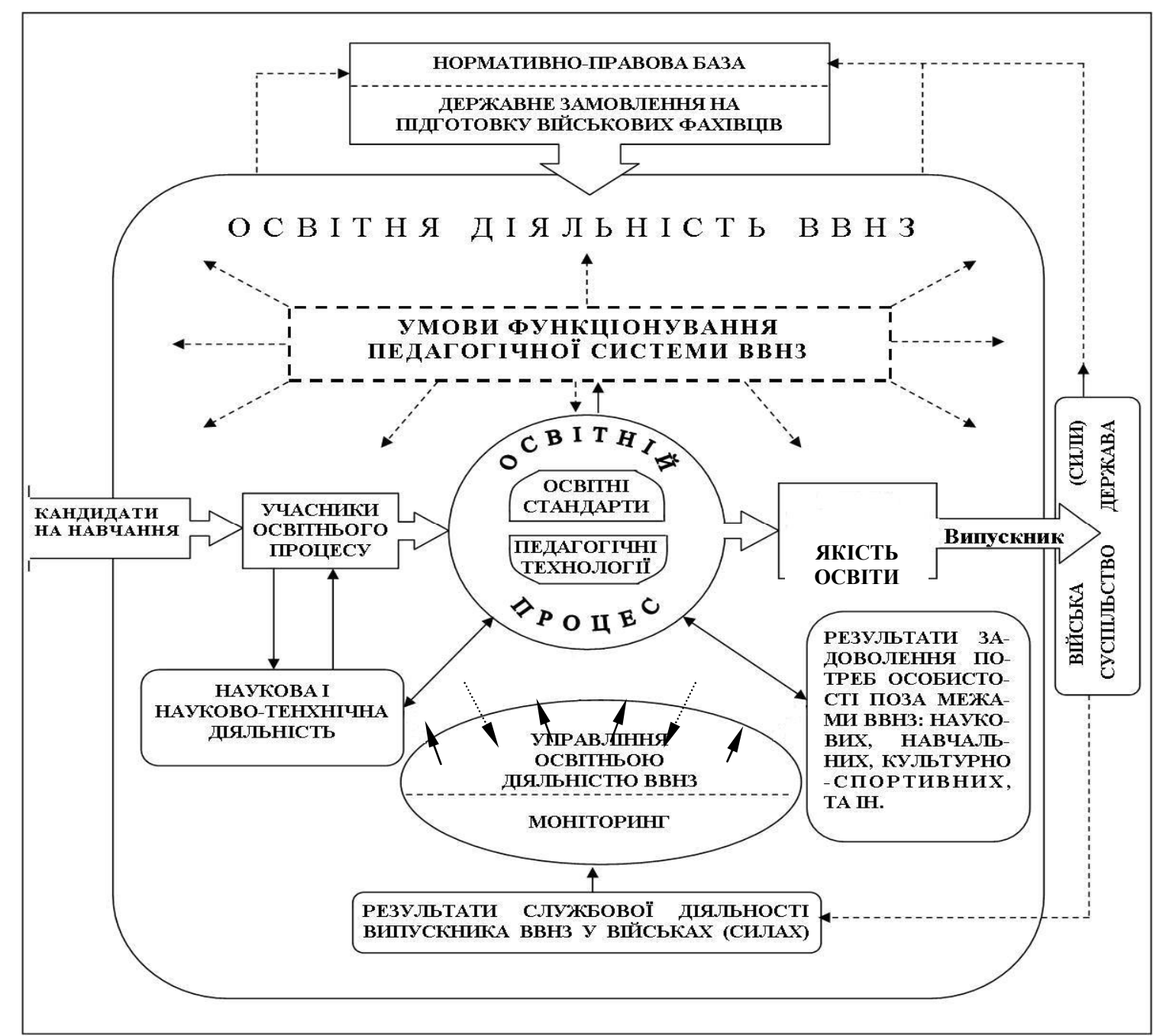

Рисунок 1. Загальна структура педагогічної системи ВВНЗ (ПС ВВНЗ).

Педагогічна система ВВНЗ функціонує в певних умовах - внутрішніх i зовнішніх, що безумовно впливають на успішність ії функціонування. Серед зовнішніх умов варто виділити такі 3 них: нормативно-правові; економічні; військово-політичні; соціально-політичні; адміністративно-управлінські; освітньо-інтеграційні; соціально-психологічні; екологічні; етичні; релігійні. До найбільш значущих внутрішніх умов, що чинять безпосередній вплив на функціонування педагогічної системи, можна віднести такі: науковоінноваційні; навчально-методичні; інформаційні; нормативно-правові; адміністративно-розпорядчі; часові; самоврядні; фінансово-економічні; санітарно-гігієнічні; побутові; естетичні; матеріально-технічні. Тобто, ПС ВВНЗ $\epsilon$ відкритою системою.На іiі функціонування впливають багато чинників, у тому числі внутрішні і зовнішні умови. Але й сама ПС, будучи системою 3 виразними властивостями самоорганізації й саморозвитку, синергетичним ефектом, може й має впливати на них, оптимізувати середовище, в якому вона функціонує. До того ж до іiі складу входить елемент з потужною внутрішньою енергетикою. Це - учасники освітнього процесу: наукові і науково-педагогічні працівники, слухачі (курсанти), управлінці, персонал забезпечення, допоміжний та технічний склад.

Провідну роль у здійсненні освітнього процесу (див. рис.1) посідають педагогічні технології. Педагогічна технологія (далі ПТ) $є$ складовою педагогічної системи i являє собою упорядковану взаємодію учасників 
освітнього процесу ВВНЗ, що має забезпечити якість підготовки здобувачів вищої військової освіти відповідно до визначених стандартів, досягнення ними заданого рівня сформованості передбачених компетентностей $[8$, с. 120]. Як складова класичної дидактики ПТ грунтується на принципах структурної і змістової цілісності, діагностичної цілеспрямованості, логічної завершеності, вимірюваності, системності та керованості. Педагогічна технологія містить у собі такі взаємопов'язані процесуальні компоненти: цільовий, мотиваційноакмеологічний, проектувально-планувальний, змістово-компетентнісний, комунікативно-перетворювальний, діагностично-оцінний, аналітичномоніторинговий, коригувальний. Основою для розроблення всіх інших компонентів ПТ є цілепокладання. Під цілями розуміється ідеальна модель бажаного результату у формуванні особистості, до якого прагнуть в процесі спеціально організованої системи послідовної взаємодії тих, хто навчаються та тих, хто навчають. Ступінь відповідності досягнутого результату цілям освіти, як ідеальної моделі бажаного, виступає показником ефективності освітнього процесу. Ефективність освітнього процесу, у свою чергу, органічно пов'язана із управлінням якістю освіти, де провідним чинником виступає система моніторингу функціонування ПС у цілому та їі основних складників (див. рис. 1).

За результатами аналізу останніх досліджень і публікацій, присвячених якості освіти, та викладу основного матеріалу даної статті може бути сформульована педагогічна закономірність щодо гарантування якості вищої військової освіти. Ця закономірність розкриває визначальний вплив створеної у ВВНЗ педагогічної системи і всебічного забезпечення освітньої діяльності на гарантоване досягнення тими, хто навчається, визначених результатів навчання відповідно до цілей освіти та вимог освітніх стандартів. Сутність даної закономірності можна викласти у такій редакції: кандидат на навчання, який пройшов професійно-психологічний відбір та вступні випробування, вмотивований на подальшу офіцерську службу і включений в оптимально створену та всебічно забезпечену педагогічну систему ВВНЗ як активний i свідомий суб'єкт учіння, має гарантовано досягати визначених результатів навчання в ході і за підсумками професійної підготовки у ВВНЗ.

Висновки. У статті, на засадах проведення дефінітивного аналізу категорій i понять щодо якості освіти, розглянуто проблему якості вищої військової освіти як результат функціонування відповідним чином створеної педагогічної системи ВВНЗ. Визначено структурні елементи ПС 3 їх взаємозв'язками та взаємозалежностями, що розкривають іiі синергетичні властивості. Досліджено сутність і структуру інноваційної педагогічної технології як системи, зміст іï складників та основи впровадження в педагогічну практику. Запропоновано концептуальні засади та закономірності гарантування якості підготовки майбутніх офіцерів Збройних Сил України у вищих військових навчальних закладах, що в подальшому, на наш погляд, можуть бути розвинуті у відповідно розроблену цілісну педагогічну концепцію та впроваджені у ВВНЗ.

ЛІТЕРАТУРА

1. Международный стандарт ISO:9000. Системы менеджмента качества - Основные положения и словарь [Электронный pecypc]. - Режим доступа: http://www.pqmonline.com/assets/files/pubs/translations/std/iso-9000-2015-(rus).pdf 
2. Закон України “Про вищу освіту” від 01.07.2014 p. № 1556-VII [Електронний ресурс]. -Режим доступу: http://zakon4.rada.gov.ua/laws/show/1556-18/page2.

3. Новейший философский словарь / Сост. А. А. Грицанов. - Мн. : Изд. В. М. Скакун, 1988. - 896 с.

4. Сучасний словник іноземних слів / Уклад. О. І. Скопенко, Т. В. Цимбалюк. - К.: Довіра, 2006. - 789 с. - (Слованики України).

5. Зельницький A. М. Вища військова освіта - проблема гарантування якості /Зельницький А. М. // Вісник НАОУ. - 2012. - № 1(26). - С. 23-25.

6. Вісник Національної академії оборони України 3 (11)/2009, Зельницький А. М., Удовенко П. І., Серветник Р М. Компетентнісна модель випускника ВВНЗ - складова системи підготовки військових фахівців С.21-26.

7. Нещадим M. I. Військова освіта України: історія, теорія, методологія, практика: Монографія. - К.: Видавничо-поліграфічний центр “Київський університет”, 2003. - 852 с.

8. Моніторинг якості підготовки військових фахівців у вищих військових навчальних закладах та військових навчальних підрозділах вищих навчальних закладів Збройних Сил України: наук.-метод. посібник. - / А. М. Алімпієв, І. В. Толок, М. І. Литвиненко та ін.; під заг. ред. І. В. Толока. - Х. : ХНУПС, 2017. - 244 с.
А. Н. Зельницкий, кандидат педагогических наук, профессор Национальный университет обороны Украины имени Ивана Черняховского

\section{КАЧЕСТВО ВЫСШЕГО ВОЕННОГО ОБРАЗОВАНИЯ КАК РЕЗУЛЬТАТ ФУНКЦИОНИРОВАНИЯ ПЕДАГОГИЧЕСКОЙ СИСТЕМЫ ВВУЗа}

В статье рассмотрены проблемы качества подготовки соискателей высшего военного образования на основе применения компетентностного подхода. Дана характеристика педагогической системе ВВУЗа как структурированной иелостной совокупности взаимосвязанных компонентов образовательной деятельности высших военных учебных заведений. Рассмотрены особенности внедрения в образовательный процесс инновационных педагогических технологий, которые максимально способствуют достижению соискателями высшего военного образования определенного уровня качества образования. Отмечена целесообразность внедрения в теорию и практику высшей военной школь концепчии гарантии качества подготовки военных специиалистов, где гарантом должен выступать ВВНЗ.

Ключевые слова: качество; качество высшего военного образования; компетентность; педагогическая система; педагогическая технология.
A. Zelnytskyi $\mathrm{PhD}$ in pedagogy, professor National Defence University of Ukraine named after Ivan Chernyahovskiy

\section{THE QUALITY OF HIGHER MILITARY EDUCATION AS A RESULT OF THE FUNCTIONING OF EDUCATIONAL SYSTEM}

The article outlines problems of higher military education quality, that based on competence approach. The characteristic of the educational system as a set of interrelated components of educational activity of higher military educational institutions. Considers specific features of introduction in educational process of innovative pedagogical technologies that should contribute to applicants of higher military education of a certain level of quality of education. The practicability of introduction to the theory and practice of the higher military school of the concept of guaranteeing the quality of training of military specialists where a guarantor must be a military high school.

Key words: quality; quality of higher military education; competency; pedagogical system; pedagogical technology. 